\title{
Tecnura
}

ESTUDIO DE CASO

\section{Methodology for the Selection of Trenchless Sewer Rehabilitation Technologies in Bogotá, Colombia}

\author{
Metodología para selección de tecnologías de rehabilitación de \\ alcantarillados sin zanja en Bogotá, Colombia
}

\author{
Edward Leonardo Tovar Romero (iD) 1 , Jorge Alberto Valero Fandiño (iD), Leonardo Cepeda \\ Ariza (iD 3
}

Fecha de Recepción: 17 de Septiembre de 2020

Fecha de Aceptación: 24 de Febrero de 2021

Cómo citar: Tovar-Romero., E.L. Valero-Fandiño., J.A. y Cepeda-Ariza., L. (2021). Methodology for the Selection of Trenchless Sewer Rehabilitation Technologies in Bogotá. Tecnura, 25(68), 105-124. https://doi.org/10.14483/22487638.15570

\begin{abstract}
Context: Operational and/or structural failures in sewer networks lead network operators to carry out rehabilitation tasks to maintain water transport conditions, which is why it isnecessary to decide on the type of intervention to be performed, that is, i) a traditional open- ditch procedure, or ii) the use of trenchless rehabilitation technologies.

Objective: This article focuses on the methodology developed and implemented in the SELECTOR program, whose purpose is to provide public service companies responsible for sewer service, as well as related professionals, with a decision tool that answers, from a technical perspective, which of the analyzed trenchless rehabilitation technologies (pipe bursting, cured-in-place pipe, slip lining, and spiral wound) is the most suitable for the rehabilitation of sewer networks.

Method: To this effect, it is necessary to consider all the influence parameters at the time of sewer rehabilitation, define the application ranges of these trenchless technologies, extract the differential variables, use fuzzy logic verbalization, determine the priority and relationship between the variables using the data mining technique known as decision trees, and develop the SELECTOR program by means of the Visual Studio 2017® platform.

Results: The differential variables for decisions regarding the application of trenchless rehabilitation technologies in underground sewerage infrastructure projects were identified. A graphic summary of the decision model was made using the verbalization diagrams and the SELECTOR program, which allows processing the information of the sewerage networks individually and for a whole sewer rehabilitation project, detailing the intervention collector to collector.

Conclusions: There are eight differential variables when deciding on sewer rehabilitation. Verbalization diagrams allow to compress the decision model and facilitate its programming, and automated decision models increase effectiveness and transparency in construction processes.
\end{abstract}

Keywords: decision tree, cured-in-place pipe, pipe bursting, sewer networks, trenchless rehabilitation, slip lining, spiral wound.

\footnotetext{
${ }^{1}$ Sanitary engineer. Consulting engineer. Bogotá, Colombia. Email: gerencia@hydratechsas.com

${ }^{2}$ Civil engineer, Master's degree in Hydrosystems. Associate professor of the Environment and Natural Resources Department of Universidad Distrital Francisco José de Caldas. Bogotá, Colombia. Contacto: javalerof@udistrital.edu.co

${ }^{3}$ Topographic engineer, specialized in Environment and Local Development. Specialized professional of the Aqueduct and Sewerage Company of Bogotá (EAAB). Bogotá, Colombia. Email: lcepedaariza@gmail.com
} 


\section{Resumen}

Contexto: Las fallas operacionales y/o estructurales en las redes de alcantarillado llevan a los operadores a realizar tareas de rehabilitación para mantener las condiciones de transporte del agua, por lo cual se requiere decidir sobre el tipo de intervención a realizar, es decir, i) procedimiento tradicional a zanja abierta o ii) uso de tecnologías de rehabilitación sin zanja.

Objetivo: Este artículo se centra en la metodología desarrollada e implementada en el programa SELECTOR, cuya finalidad es proveer a las empresas de servicios públicos responsables del servicio de alcantarillado, así como a los profesionales relacionados, una herramienta de decisión que responda desde la perspectiva técnica cuál de las tecnologías de rehabilitación sin zanja analizadas (pipe bursting, tubería curada en sitio, revestimiento deslizante continuo y revestimiento con tubería en espiral) es la más adecuada para realizar la rehabilitación de redes de alcantarillado.

Método: Para ello es necesario considerar todos los parámetros de influencia al momento de la rehabilitación de alcantarillados, definir los rangos de aplicación de estas tecnologías sin zanja, extraer las variables diferenciales, usar verbalización de lógica difusa, determinar la prioridad y relación entre las variables mediante la técnica de minería de datos conocida como árboles de decisión, y desarrollar el programa SELECTOR mediante la plataforma Visual Studio 2017®.

Resultados: Se identificaron las variables diferenciales para la decisión de aplicación de tecnologías de rehabilitación sin zanja en proyectos de infraestructura subterránea de alcantarillados. Se realizó un resumen gráfico del modelo de decisión mediante los diagramasde verbalización y el programa SELECTOR, que permite procesar la información de las redes de alcantarillado de manera individual y para todo un proyecto de rehabilitación de alcantarillado, detallando la intervención colector a colector.

Conclusiones: Existen ocho variables diferenciales al momento de decidir sobre la rehabilitación de alcantarillados. Los diagramas de verbalización permiten comprimir el modelo de decisión y facilitan su programación, y los modelos de decisión automatizados aumentan la efectividad y la transparencia en los procesos de construcción.

Palabras clave:árbol de decisión, tubería curada en sitio, pipe bursting, redes de alcantarillado, rehabilitación sin zanja, revestimiento deslizante continuo, revestimiento con tubería en espiral.

\section{Table of Contents}

$\begin{array}{ll}\text { BACKGROUND CONCEPTS } & 107\end{array}$

Cured-in-place pipe $(\mathrm{CIPP}) \quad \ldots \ldots \ldots \ldots \ldots \ldots$. . . . . . . . . . . . 108

Pipe bursting $(\mathrm{PB}) \ldots \ldots \ldots \ldots \ldots \ldots \ldots$. . . . . . . . . . . . . . . . . . . . . . . . . . . . . . . . . . . . . . . . . . . . . . . . . .

Spiral wound $(\mathrm{SW}) \ldots \ldots \ldots \ldots \ldots \ldots \ldots$

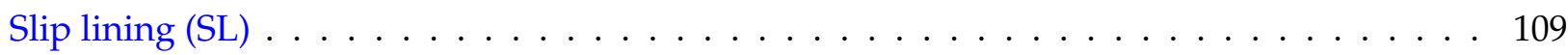

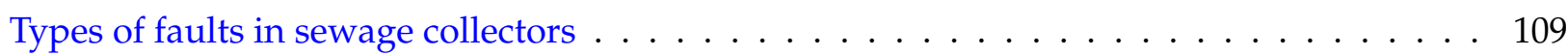

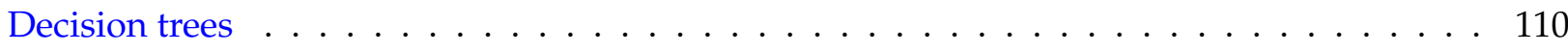

$\begin{array}{ll}\text { METHODOLOGY } & 110\end{array}$ 


\section{INTRODUCTION}

In Colombia, the Aqueduct and Sewerage Company of Bogotá ("Empresa de Acueducto y Alcantarillado de Bogotá", EAAB), a public services company, has implemented technified, minimally invasive, and very precise inspection systems for network monitoring and cadastre. However, it is still necessary to open a trench to access the pipe when there is a need to repair cracks or rectify misalignments or cross-section losses, among others (EAAB, 2001).

For this reason, trenchless renovation and rehabilitation technologies (TRTs) represent an optimal intervention alternative (Wavin, 2013) for the performance of punctual or general maintenance of simple or complex sewage networks. These can be implemented in large cities, thus generating a minor impact in terms of logistics, environmental issues (EPA, 2007, Vera, 2016), landscape (Wavin, 2013), operations (Sullivan, 2002), economics (Pyzoha, 2013), and security (Sullivan, 2002), both for workers and citizens.

This document initially answers the following question: what are the most important characteristics of a sewer network or section when defining the most appropriate trenchless sewer network rehabilitation technology? It is important to clarify that four TRTs were analyzed, namely curedinplace pipe (CIPP) (Mínguez, 2015, Asociación Ibérica de Tecnología sin Zanja, 2018), Slip Lining (SL) (Wavin, 2013,Mínguez, 2015), pipe bursting (PB) (EAAB, 2010b,EAAB-Treltec, 2010,Chan, 2017), and Spiral Wound (SW) (Mongue, 2017, Asociación Ibérica de Tecnología sin Zanja, 2018) The next main question is how were the rules that allow the interaction of the previously identified variables determined?' Finally,there is a description of the way in which the variables and the identified rules feed the SELECTOR program (developed under the Visual Studio environment), a software that makes it possible to answer, from a technical point of view, which of the four analyzed technologies should be used to rehabilitate a sewer network.

\section{BACKGROUND CONCEPTS}

Understanding the repair of sewerage networks requires the appropriation of two basic concepts: renovation and rehabilitation. On one hand, renovation refers to the change of an existing network when it is necessary to modify the design parameters, especially the flow to be transported. On the 


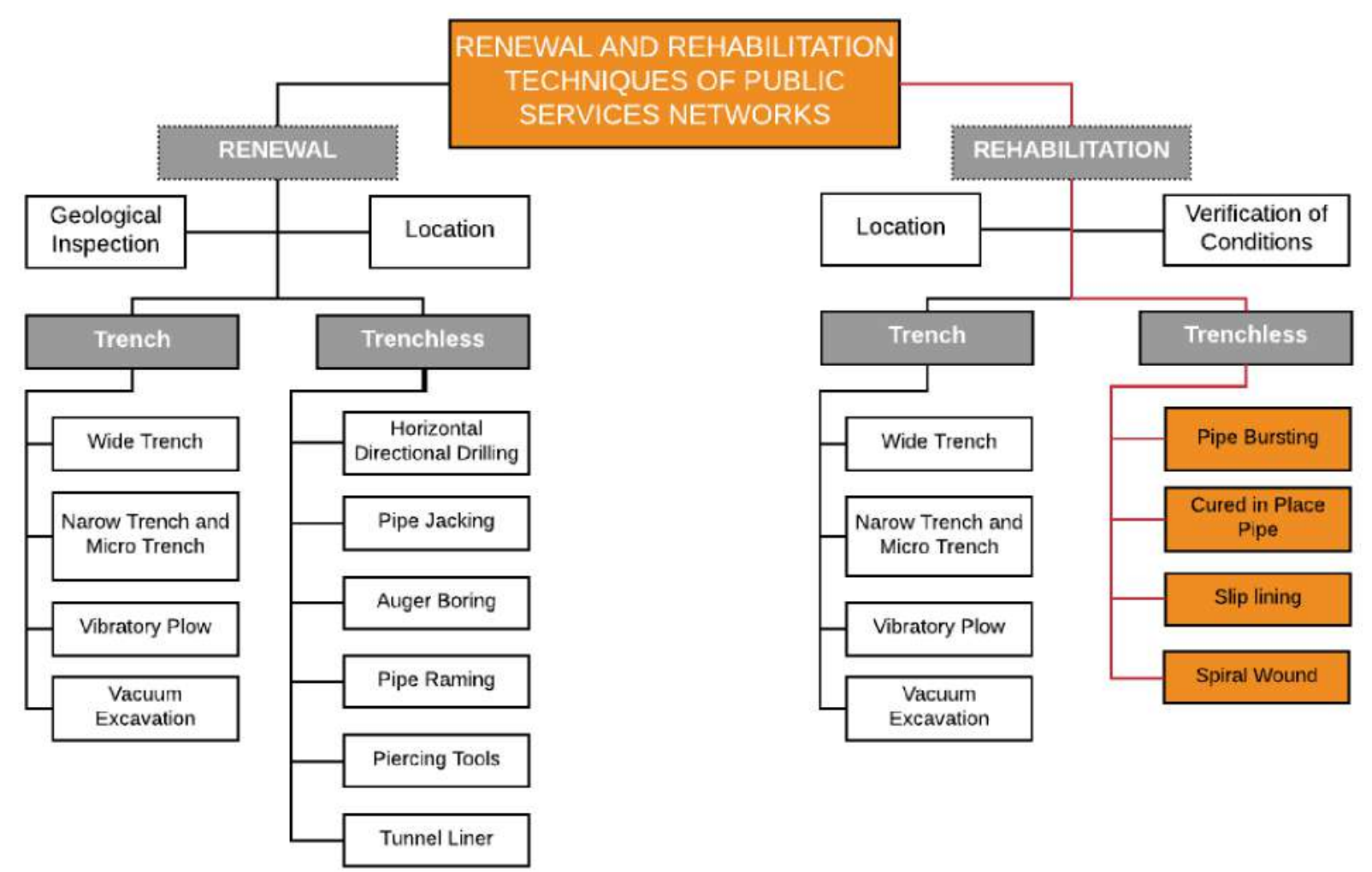

Figure 1. Techniques for renovation and rehabilitation of public service networks

Source: Adapted from Hashash and Finno (2008).

other hand, rehabilitation consists of changing the collectors, which have deteriorated due to age, fissures, faults, etc., while maintaining the original design parameters.

The general techniques of renovation and rehabilitation of public service networks can be seen in Figure 1. Following is a brief description of the four trenchless sewer rehabilitation technologies analyzed in this research.

\section{Cured-in-place pipe (CIPP)}

It is a technology in which a felt sleeve impregnated with resin is introduced into the pipe for its rehabilitation. Once positioned, this sleeve is inflated with compressed air and cured with water vapor or ultraviolet light. With this technology, tubes of different cross sections can be rehabilitated. The reopening of the connections is made manually and/or with unmanned vehicles equipped with a milling head (Asociación Ibérica de Tecnología sin Zanja, 2018,EAAB, 2015a,EAAB, 2015c) 


\section{Pipe bursting (PB)}

It is a pipe replacement technology in which, after the rupture of the old pipe through the use of an expander head (pulled by a winch that simultaneously sends pipe fragments to the ground), a new line of plastic pipe is inserted (EAAB, 2010a, EAAB-Treltec, 2010, Chan, 2017). This technology, like CIPP, requires the installation of a bypass.

\section{Spiral wound (SW)}

It is a technology that involves the internal coating of the pipe for its rehabilitation. It consists of feeding a line of plastic material by means of a spiral winding head, with which a new pipe of any transversal section is formed (circular, elliptical, rectangular, or triangular) without requiring a bypass. Subsequently, a polymeric slurry is injected for the purpose of filling the space between the shelter pipe and the new pipe (Mongue, 2017, Asociación Ibérica de Tecnología sin Zanja, 2018)

\section{Slip lining (SL)}

This rehabilitation technology consists of a pre-made plastic U- or H-pipe, which is inserted into the pipe in question. After positioning the plastic pipe, it is inflated with steam until it fits the old pipe. (Wavin, 2013,Mínguez, 2015).

\section{Types of faults in sewage collectors}

Sewer network collectors may have different types of faults, and these can be classified into two major groups: structural failures and operational failures (EAAB, 2001). It is possible that a network has more than one type of failure, and also that these faults are correlated. On one hand, structural failures obey the serviceability limit state, above which the existing deformations or the structural capacity of the system is overcome. These failures are generally due to deficiencies in the design and/or construction of the sewerage, as well as the increase of loads on the network of collectors or the movement and displacement of the land that houses the network (EAAB, 2001). These failures usually result in deflection, rupture, or misalignments, which, in addition to affecting the transport of wastewater, generatesignificant damage both on the platform and in the stabilization layers of the roads, thus causing depressions in the terrain.

On the other hand, operational failures are related to the loss of the driving capacity established in the design. This type of failure occurs due to the loss of cross-section in the collectors, which is caused by the accumulation of sediments or a sudden increase in flow due to wrong connections, obstructions, population increase, change of land use, or an increase in infiltration (EAAB, 2001). 


\section{Decision trees}

A decision tree (Rosado-Gómez \& Verjel-Ibáñez, 2015) is a hierarchical structure, composed of nodes, branches, and leaves, that seeks to identify patterns or rules in a data set (Carvajal Montealegre, 2015). The nodes represent the characteristics or variables of study and are organized according to their relevance through the concepts of entropy and information gain (Jiawei et al., 2012, Rokach \& Maimon, 2007). The branches, which interconnect nodes, constitute the attributes of each of the characteristics. At the end of each branch are the leaves, which represent the final response for each rule obtained (Jiawei et al., 2012, Rokach \& Maimon, 2007).

\section{METHODOLOGY}

This work arises from the EAAB's need for a tool that allows responding to the specific conditions of a collector. What is the most appropriate trenchless rehabilitation methodology? This question is solved through the SELECTOR program, a product of the present research.

The area of study was the city of Bogotá, Colombia, where, once the need was recognized, it was decided to structure a decision model in which base information could be used todetermine the starting parameters, with the purpose of making technically optimal decisions for the application of TRTs.

The first step was consulting the information contained in the following EAAB standards: NS-061v.1.1. (EAAB, 2001), NP-110-v.0.0 (EAAB, 2015a), NS-150-v.0.0 (EAAB, 2015b), NS-152-v.0.0 (EAAB, 2015c), and NS-058-v-3.2 (EAAB, 2010a). The following design manuals were also consulted: Applications without Pressure (Wavin, 2013) and title D of the RAS (Ministerio de Vivienda, Ciudad y Territorio, 2017). Some information was also obtained through various bibliographical sources and references of international events, such as the NO-DIG®. Additionally, the collected and generated information was reviewed, processed, and exhaustively analyzed, thus establishing a parametric table, which was subjected to debugging by differential features until a product was obtained, by means of which, in the first instance, it was possible to extract the rules of the model using decision trees.

In a second instance, after the identification of the rules generated by the decision tree, the SELECTOR software was programmed.

\section{RESULTS}

According to the review of the four analyzed TRTs (PB, CIPP, SL, and SW), the application ranges of each technology were established as shown in Table 1, in which five categories or analysis variables were defined: design, material of the existing pipeline, type of fault, soil, and water to be transported. 
Next, the description of each of the categories is presented.

In the design category, the following characteristics of the pipes were analyzed: minimum and maximum diameter, degree of deterioration, minimum and maximum length, minimum coverage, and cross section. Regarding the latter, it should be noted that the SW techniquecan be applied in two cases: for circular cross sections with diameters smaller than $0,56 \mathrm{~m}$ (22 in) or for cross sections of any shape with a hydraulic depth greater than $0,61 \mathrm{~m}$ (24 in). (circular $\leq 22 \mathrm{in}$, for every section $\geq 24$ ). On the other hand, the degree of deterioration (symbolized by the expression $\dot{x}$ op-est) is obtained by calculating the arithmetic mean of the operational and structural deterioration degrees previously obtained from network inspections.

In the second category, existing material, are the materials that commonly make up the pipes of the sewer network.

The category of failure includes the possible findings of the operational and/or structural status resulting from the preliminary inspection.

As for the type of soil, reference is made to the material surrounding the collector to be rehabilitated. In this category is the term "Not_relevant"which indicates that the characteristic is not important for the analyzed TRT.

Finally, the category regarding the liquid to be transported (symbolized by the acronym $\mathrm{H}_{2} \mathrm{O}$ ) refers to the characteristics of the wastewater that may affect the new interior coating of the rehabilitated pipeline. For PB and SW, the criterion called 'according to the new one' was established, which seeks to express that the range of resistance to acidic or alkaline water, as well as to high and low temperature water, depends on the new material to be installed.

Once the ranges and variables recorded in Table I were set, the first step was to identify the common characteristics for all four technologies, in order to reduce the number ofcharacteristics to be processed. Thus, if a variable had the same application range for the four analyzed technologies, it meant that said variable was irrelevant when defining the most appropriate technology.

After a detailed analysis of the information in Table $\mathbf{I}$, three categories were eliminated: soil type and $\mathrm{H}_{2} \mathrm{O}$, as well as the minimum coverage characteristic belonging to the design category. Additionally, since the characteristics of misalignment, deflection, and reduction of the transverse area, belonging to the failure category, had variable application ranges for each TRT, they were considered as individual categories.

With respect to the subtraction of the $\mathrm{H}_{2} \mathrm{O}$ category, the application ranges are within the conditions that both the resins used in CIPP and the coextruded polymers used for the implementation of $\mathrm{SL}, \mathrm{PB}$, and SW can support. For this reason, none of the ranges contained in this category is relevant.

Regarding the minimum coverage of the pipes, by reviewing article 139 of the current Technical Regulation of the Sector of Drinking Water and Basic Sanitation RAS (?, Ministerio de Vivienda, Ciudad y Territorio, 2017), it was found that, for pedestrian or green areas, the depth at the key level of the section must be at least $0,75 \mathrm{~m}$ (29,53 in), and, for vehicular roads, the depth at the key level of the section must be at least 1,20 m (47,24 in). Considering the above, the minimum coverage category 
Methodology for the Selection of Trenchless Sewer Rehabilitation Technologies in Bogotá, Colombia Tovar-Romero., E.L. Valero-Fandiño., J.A. y Cepeda-Ariza., L.

Table I. Application ranges of trenchless rehabilitation technologies (TRTs)

\begin{tabular}{|c|c|c|c|c|c|}
\hline 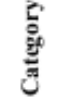 & $\begin{array}{l}\text { Collector } \\
\text { features }\end{array}$ & Pipe Bursting & CIPP & Slip lining & Spiral wound \\
\hline \multirow{7}{*}{ 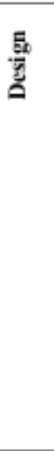 } & $\begin{array}{l}\text { Minimum diameter } \\
(\mathrm{m})\end{array}$ & $0,10 \mathrm{~m}(4 \mathrm{in})$ & $0,15 \mathrm{~m}(6 \mathrm{in})$ & $0,15 \mathrm{~m}(6 \mathrm{in})$ & $0,15 \mathrm{~m} \mathrm{(6}$ in) \\
\hline & $\begin{array}{l}\text { Maximum diameter } \\
(\mathrm{m})\end{array}$ & $0,91 \mathrm{~m}$ (36 in) & $\begin{array}{l}3,15 \mathrm{~m}(124 \\
\text { in) }\end{array}$ & $0,51 \mathrm{~m}(20 \mathrm{in})$ & $4,98 \mathrm{~m}$ (196 in) \\
\hline & $\begin{array}{c}\text { Degree of } \\
\text { deterioration } \\
(\dot{x} \text { op- } \\
\text { est,dimensionless) }\end{array}$ & $3 \sim 5$ & $0 \sim 3$ & $0 \sim 2$ & $0 \sim 2$ \\
\hline & Maximum length (m) & 137,16 & 304,80 & 600 & Any \\
\hline & Minimum length (m) & 0 & 0 & 0 & 0 \\
\hline & $\begin{array}{l}\text { Minimum coverage } \\
(\mathrm{m})\end{array}$ & $\begin{array}{c}0,30 \mathrm{~m} / 0,03 \mathrm{~m} \\
(1 \mathrm{ft} / 1 \mathrm{in})\end{array}$ & The existing & The existing & The existing \\
\hline & Cross section & Circular & All & Circular & $\begin{array}{c}\text { Circular ( } \leq 22 \text { in, for every } \\
\text { section } \geq 24)\end{array}$ \\
\hline \multirow{13}{*}{ 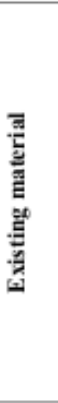 } & Steel & Non-applicable & Applicable & Applicable & Applicable \\
\hline & Corrugated metal & Non-applicable & Applicable & Applicable & Applicable \\
\hline & Galvanized & Non-applicable & Applicable & Applicable & Applicable \\
\hline & Reinforced concrete & Non-applicable & Applicable & Applicable & Applicable \\
\hline & Ductil iron & Non-applicable & Applicable & Applicable & Applicable \\
\hline & PP & Non-applicable & Applicable & Applicable & Applicable \\
\hline & PEAD & Non-applicable & Applicable & Applicable & Applicable \\
\hline & PVC & Non-applicable & Applicable & Applicable & Applicable \\
\hline & Concrete & Non-applicable & Applicable & Applicable & Applicable \\
\hline & Asbestos cement & Non-applicable & Applicable & Applicable & Applicable \\
\hline & Stoneware & Applicable & Applicable & Applicable & Applicable \\
\hline & Molten iron & Applicable & Applicable & Applicable & Applicable \\
\hline & Fiberglass & Applicable & Applicable & Applicable & Applicable \\
\hline \multirow{5}{*}{ 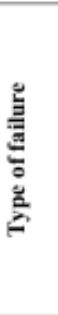 } & Misalignment (\%) & $\begin{array}{l}\text { Without } \\
\text { restrictions }\end{array}$ & $\leq 10 \%$ & No & No \\
\hline & Deflection (\%) & $\begin{array}{l}\text { Without } \\
\text { restrictions }\end{array}$ & $\leq 60 \%$ & No & No \\
\hline & $\begin{array}{l}\text { Cross-sectional area } \\
\text { reduction }(\%)\end{array}$ & $\begin{array}{l}\text { Without } \\
\text { restrictions }\end{array}$ & $\leq 40 \%$ & No & No \\
\hline & Fissure & $\begin{array}{l}\text { Without } \\
\text { restrictions }\end{array}$ & $\mathrm{Si}$ & $\mathrm{Si}$ & $\mathrm{Si}$ \\
\hline & Fracture & $\begin{array}{l}\text { Without } \\
\text { restrictions }\end{array}$ & $\mathrm{Si}$ & $\mathrm{Si}$ & $\mathrm{Si}$ \\
\hline \multirow{6}{*}{ 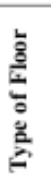 } & Original filling & Not relevant & Not relevant & Not relevant & Not relevant \\
\hline & Expandable clay & Not relevant & Not relevant & Not relevant & Not relevant \\
\hline & Loose pebble & Not relevant & Not relevant & Not relevant & Not relevant \\
\hline & Sand & Unfavorable & Not relevant & Not relevant & Not relevant \\
\hline & Compact clay & Unfavorable & Not relevant & Not relevant & Not relevant \\
\hline & Sand rock & Unfavorable & Not relevant & Not relevant & Not relevant \\
\hline \multirow{3}{*}{$\underset{\nexists}{0}$} & Acid & $\begin{array}{l}\text { According to the } \\
\text { new }\end{array}$ & 0,5 & 2 & According to the new \\
\hline & Alkaline & $\begin{array}{l}\text { According to the } \\
\text { new }\end{array}$ & 10,5 & 12 & According to the new \\
\hline & Temperature $\left({ }^{\circ} \mathrm{C}\right)$ & $\begin{array}{l}\text { According to the } \\
\text { new }\end{array}$ & 172 & 172 & According to the new \\
\hline
\end{tabular}

Source: Primary author.

was eliminated, since, even in the most restrictive case (PB), the depths of the collectors at key level are higher than a foot for each inch of expansion required by this technology.

Once the initially identified variables were reduced, the resulting variables were analyzed by 
means of the search for the differential features that correspond to those application values, for which it is feasible to use only one of the four analyzed TRTs. This analysis not onlyreduces the number of paths to be processed, but also facilitates the establishment of model rules.

A rule corresponds to the configuration of variables that lead to define which TRT can be used. It should be made clear that the response of a rule may also be the impossibility of using any TRT.

After debugging the characteristics reported in Table I, eight variables were obtained: pipe diameter, pipe length, degree of deterioration, cross section, material, misalignment, deflection, and reduction of the cross-sectional area. The variables, along with the ranges adopted for each verbalization, are shown in Figures 2-9. Verbalization consists in converting a numerical variable into text, that is, assigning qualifying adjectives (Real Academia Española, n.d.) to the ranges of the variables according to the perception of the data set.

The pipe diameter variable was verbalized in three categories, as shown in Figure 2. Thus, the existing 48 commercial diameters (which range from 4 in to 196 in) were reduced to three: small diameter (0-5,9 in), medium diameter (6-124 in), and large diameter (> $124 \mathrm{in})$.

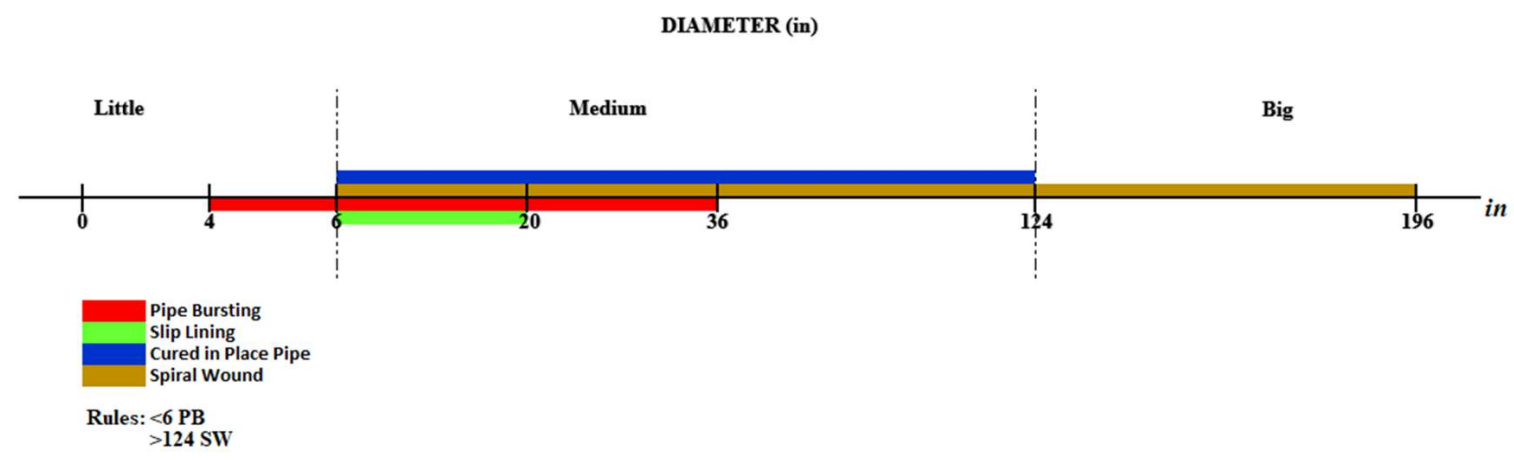

Figure 2. Verbalization of the pipe diameter variable

Source: Primary author.

The verbalization criterion for the variable length of the pipeline is supported by article 157 of the RAS 2017 (Ministerio de Vivienda, Ciudad y Territorio, 2017), for which the length between inspection wells must have a maximum distance of $120 \mathrm{~m}$ for sections with flow contribution and can be increased to $300 \mathrm{~m}$ for interceptors and final emissaries without flow contribution. In agreement with the above, the variable was verbalized in conventional length (which includes diameters $\geq 137$ $\mathrm{m}$ ) and extraordinary length (for diameters $<137 \mathrm{~m}$ ). In this particular variable, it is found that, for a length greater than $600 \mathrm{~m}$, only SW applies. However, this scenario is not considered a rule since it is not possible to find wastewater collectors with such a length.

On the other hand, the degree of deterioration variable ( $\dot{x}$ op-est) was verbalized in three categories: small degree of deterioration ( $\dot{x}$ op-est $\leq 2)$, medium degree of deterioration $(2<\dot{x}$ op-est $\leq 3)$, and high degree of deterioration ( $\dot{x}$ op-est $>3$ ), as shown in Figure 4. 


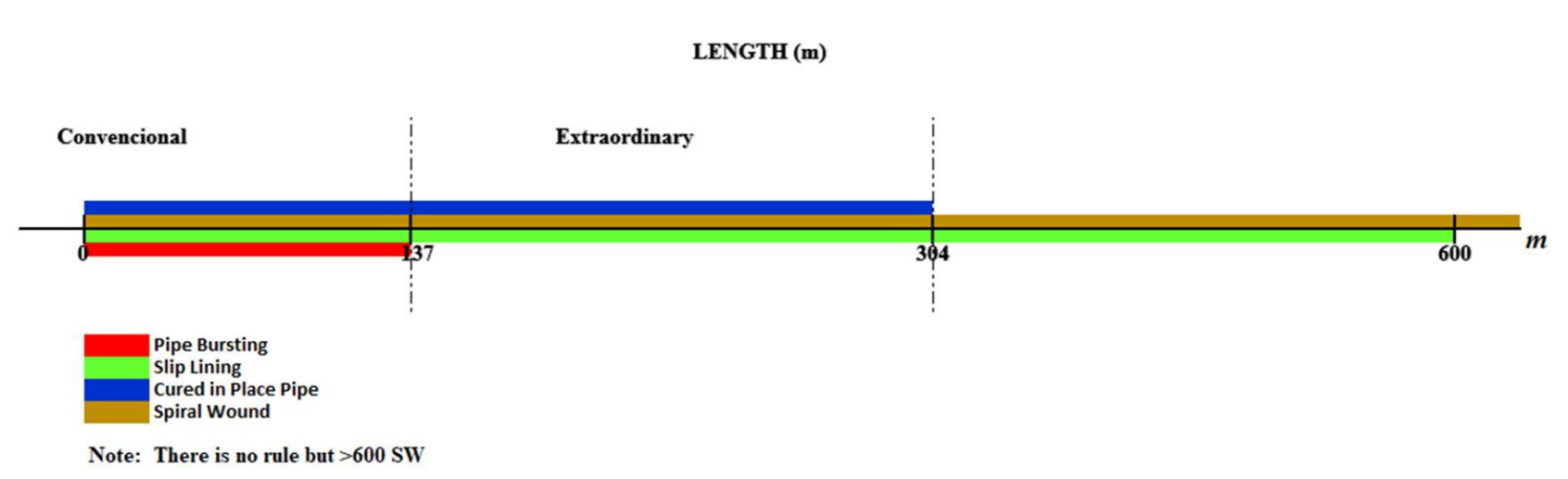

Figure 3. Verbalization of the collector length variable

Source: Primary author.

The cross section variable was verbalized in two possibilities: circular and non-circular, so that the non-circular category includes the following cross sections: elliptical, rectangular, square, triangular, etc. This is shown in Figure 5.

The 13 materials outlined in Figure 6 were grouped into rigid and non-rigid materials. This verbalization was defined considering that PB technology is the only one that has a restriction with respect to the material; since it is the only method that does not use the existing pipe as a shelter, it requires previous analysis regarding the material of the pipe to be replaced because the radial force exerted for the rupture of the existing pipe varies depending on its material. For this reason, if the material is rigid, it will be susceptible to fragmentation, which facilitates the passage of the breakage head through the pipe to be replaced, thus avoiding jamming. In the event that the material to be replaced is not rigid, it is possible for the breakage head to become jammed.

\section{LEVEL DAMAGE}

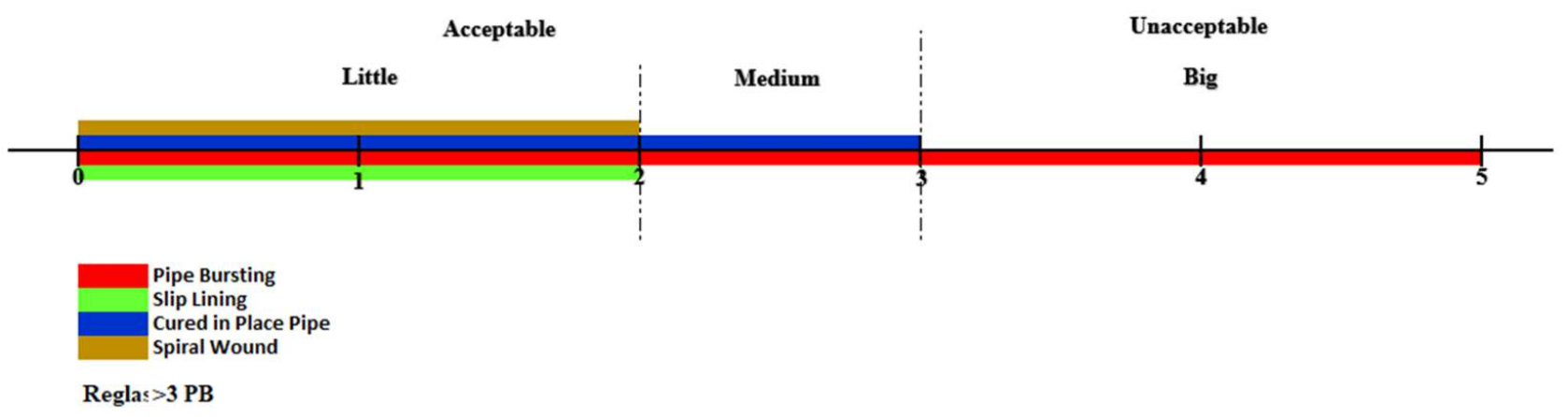

Figure 4. Verbalization of the degree of deterioration variable

Source: Primary author. 


\section{CROSS SECTION}

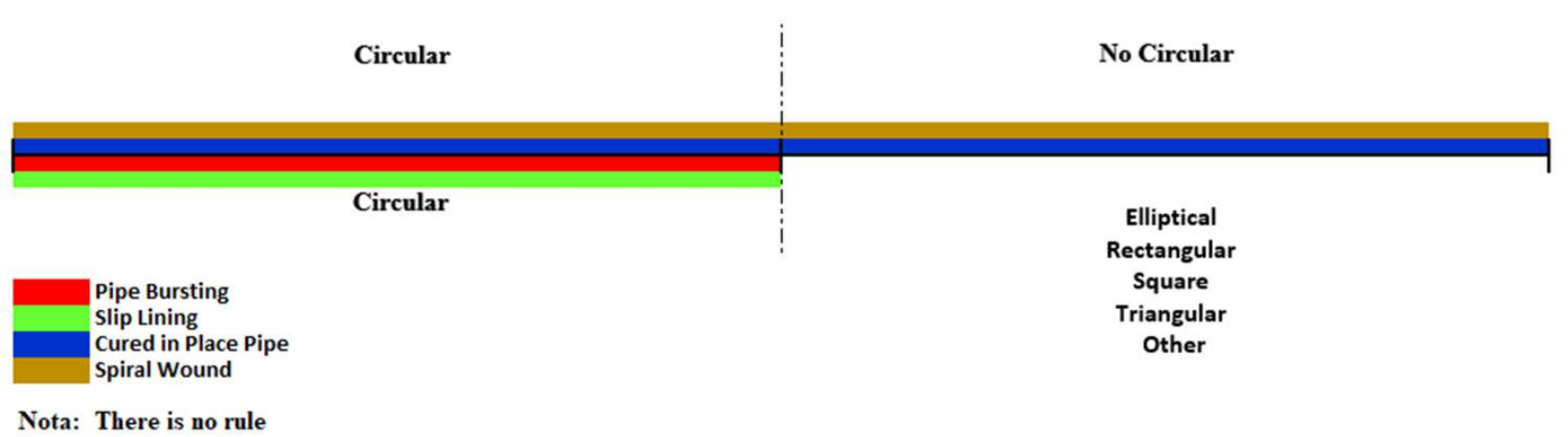

Figure 5. Verbalization of the cross section of the collector variable

Source: Primary author.

Given that CIPP, SL, and SW are technologies that use the existing pipe as a shelter, misalignment plays an important role, since it represents one of the variables that restricts the application of these three TRTs. As shown in Figure 7, SW and SL cannot be used in pipes with significant misalignments, i.e., higher than $1 \%$, while CIPP has an application range of up to $10 \%$. For this reason, the misalignment variable was verbalized into null, small, and large. It is important to keep in mind that PB does not require a shelter pipe, so this technology applies to any range of misalignment.

The variables deflection and reduction of the cross section of the collector were verbalized following the same criteria established for the misalignment variable (see Figures 8 and 9).

By comparing Figures 7 to 9 , it is made clear that the verbalization range fluctuates according to

MATERIAL

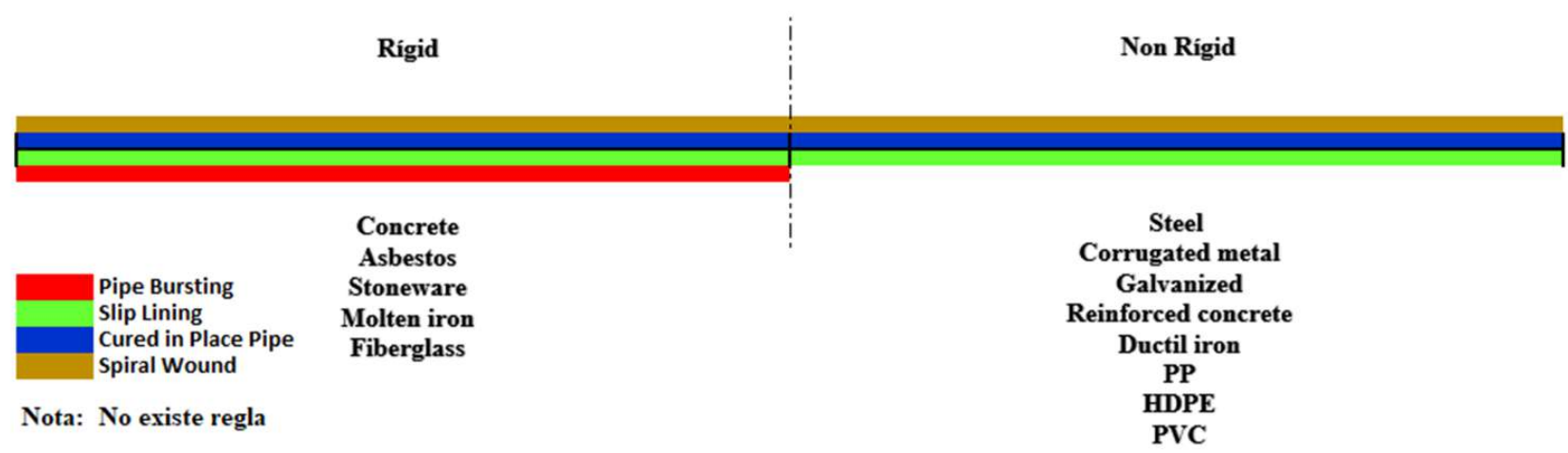

Figure 6. Verbalization of the material variable

Source: Primary author. 


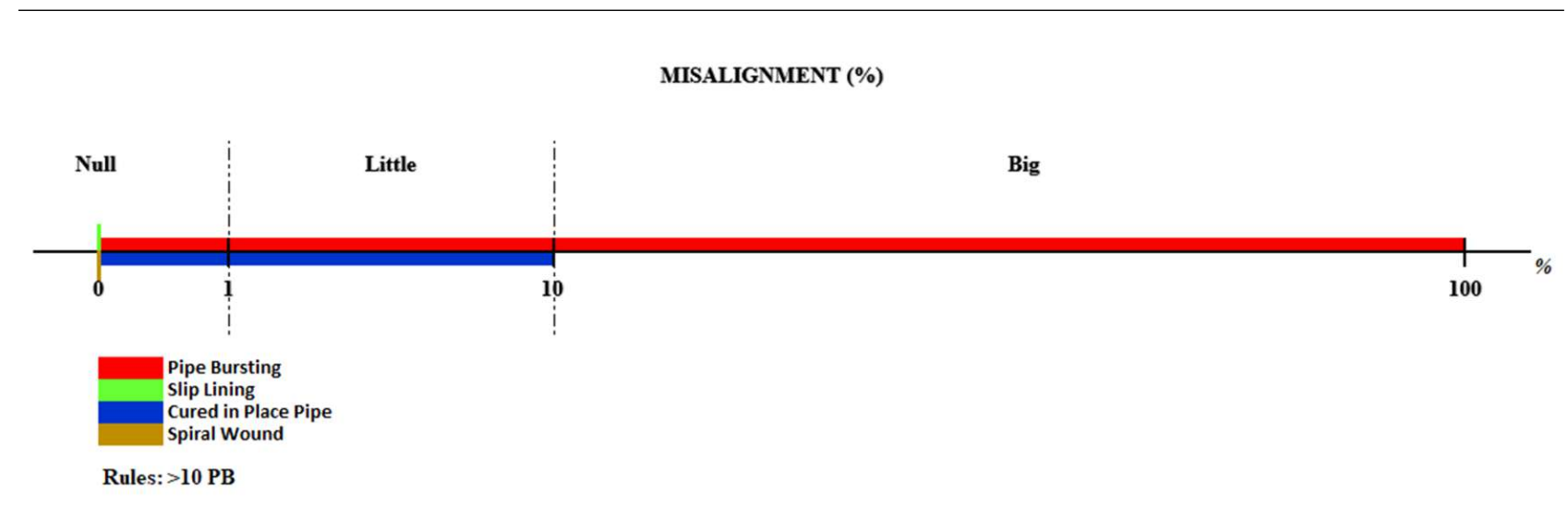

Figure 7. Verbalization of the misalignment variable

Source: Primary author.

DEFLEXION (\%)

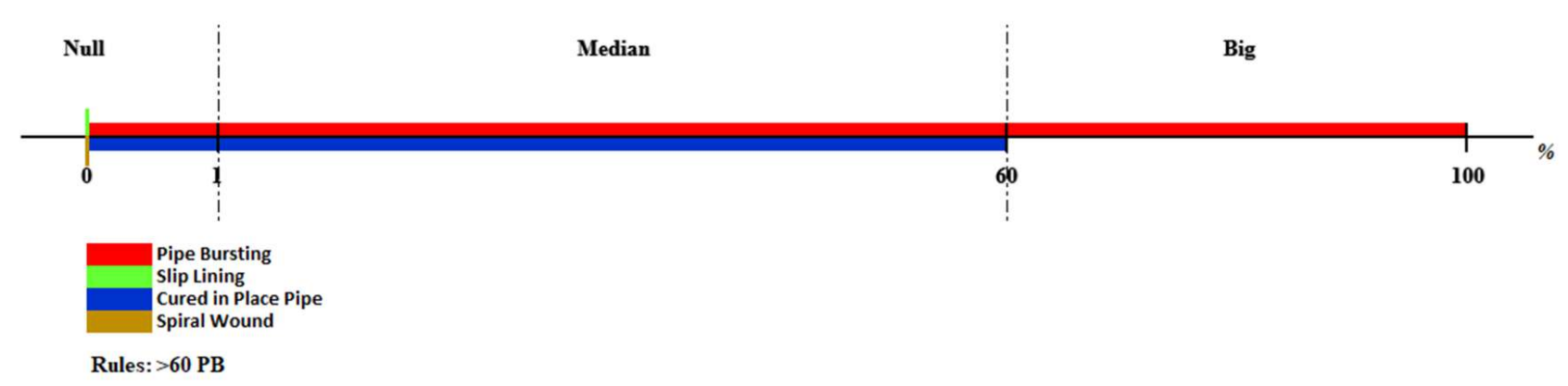

Figure 8. Verbalization of the collector deflection variable

Source: Primary author.

CROSS-SECTIONAL AREA LOST (\%)

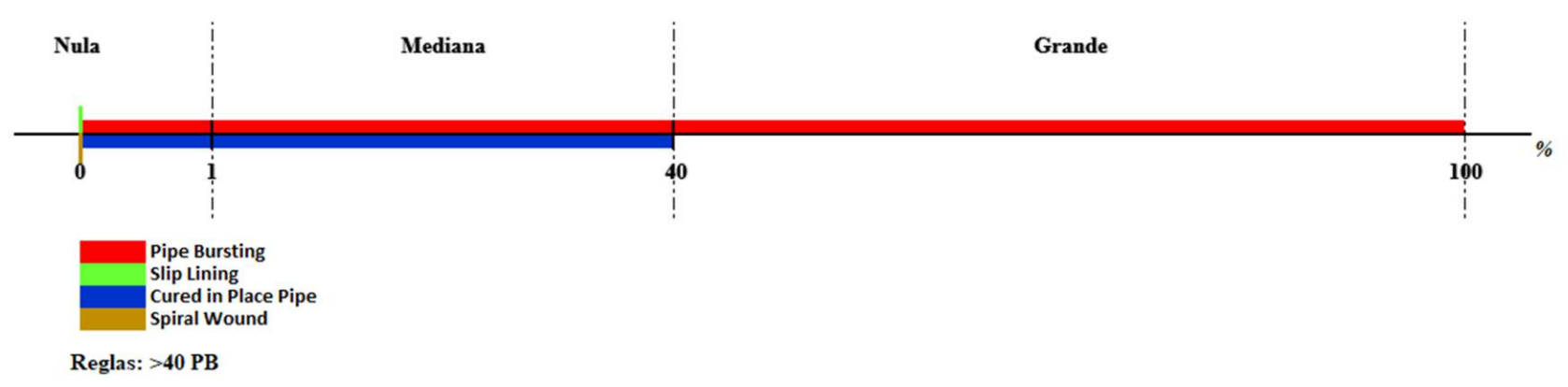

Figure 9. Verbalization of the cross-section reduction variable

Source: Primary author. 
the application range of application CIPP, and it remains null for SL and SW. Thus, PB technology works for all ranges of the misalignment variable, as well as for deflection and reduction of the cross section of the collector, and its application becomes the rule for cases in which the variable is cataloged as large.

Once the variables were refined and verbalized, it was possible to go from more than 34 million rules (34 369 920) to less than two thousand rules (1944). The summary of non- verbalized and verbalized variables can be seen in Table II.

Table II. Domains of the non-verbalized and verbalized variables

\begin{tabular}{ccc}
\hline Variable & $\begin{array}{c}\text { Domain of the } \\
\text { non-verbalizedvariable }\end{array}$ & $\begin{array}{c}\text { Domain of the } \\
\text { verbalizedvariable }\end{array}$ \\
\hline Diameter & 48 & 3 \\
\hline Length & 34 & 2 \\
\hline Degree of deterioration & 10 & 3 \\
\hline Cross section & 6 & 2 \\
\hline Material & 13 & 2 \\
\hline Misalignment & 3 & 3 \\
\hline Deflection & 3 & 3 \\
\hline Reduction of the cross area & 3 & 1944 \\
\hline Total paths to be processed & 34369920 & 3 \\
\hline
\end{tabular}

Source: Primary autor.

As an example, it is shown in Table II that the diameter variable had 48 possible answers without verbalizing, and, once it was verbalized, its answers were reduced to three. Next, the input parameter table was created for the analysis using the data mining technique called 'decision tree'. This table had nine columns, eight of them corresponding to each of the variables described above, and the ninth column called 'Appropriate Technology' (see Table III). In this table, it can be seen that the possible answers offered by SELECTOR are eight, out of which seven correspond to the application of one or several of the analyzed technologies, while the eighth option corresponds to 'None of the Technologies Analyzed Applied' (NTAA).

For example, in the first row of Table III, the particular situation in which the diameter is medium, the length conventional, the degree of deterioration average, the cross section circular, the material rigid, the misalignment small, and both the deflection and the cross- section loss are zero, it is possible to use two TRTs: PB and CIPP. 
Methodology for the Selection of Trenchless Sewer Rehabilitation Technologies in Bogotá, Colombia Tovar-Romero., E.L. Valero-Fandiño., J.A. y Cepeda-Ariza., L.

Table III. Example of a segment of the parametric table, input for the analysis through decision trees

\begin{tabular}{ccccccccc}
\hline Diameter & Length & $\begin{array}{c}\text { Level } \\
\text { Damage }\end{array}$ & Cross & Section & Material & Misalignment & Deflection & Sectional \\
area lost & Technology \\
\hline Medium & Conventional & Medium & Circular & Rigid & Small & Null & Null & PB_CIPP \\
\hline Medium & Conventional & High & Circular & Rigid & Small & Null & Large & PB \\
\hline Medium & Extraordinary & Medium & Circular & Rigid & Small & Null & Medium & CIPP \\
\hline Large & Conventional & Low & Circular & Rigid & Null & Null & Null & SW \\
\hline Medium & Conventional & Low & Non-Circular & Rigid & Null & Null & Null & SW_CIPP \\
\hline Medium & Conventional & Low & Circular & Non-Rigid & Null & Null & Null & CIPP_SW_SL \\
\hline Medium & Conventional & Low & Circular & Rigid & Null & Null & Null & PB_SL_CIPP_SW \\
\hline Medium & Conventional & Medium & Circular & Non-Rigid & Large & Null & Null & NTAA \\
\hline
\end{tabular}

Source: Primary autor.

For the completion of the first eight columns of the parametric table, the combination of all verbalized ranges was performed, thus obtaining 1944 possible combinations. Subsequently, the most appropriate technology or technologies for each of the combinations was determined.

After defining the response for each of the 1944 combinations, the analysis was carried out using decision trees, in order to further reduce the number of combinations and avoid ambiguities when preparing the SELECTOR program. The decision tree was elaborated using the J48 algorithm incorporated in the free distribution software called Weka ${ }^{\circledR}$ (niversity of Waikato, 2016). In this way, the 1 944 combinations were reduced to 100 rules, which were validated one by one to verify their veracity. These rules make up the decision-making engine of SELECTOR.

As an example of the reduced rules, it was found that, when the diameter is small, the length is conventional, the cross section is circular, the material is non-rigid, and none of the Technologies Analyzed Applies (NTAA). This simple rule summarizes 81 of the 1944 possible rules.

In the final stage of the process, SELECTOR was programmed under the Visual Studio® platform. This program allows identifying the most appropriate TRT based on the eight variables cited in Table II and the 100 previously validated rules. Additionally, the program allows the incorporation of information from the collectors regarding the network's cadastre, such as service area, location, collector identifier, and initial and final well identifier. Figures 11 to show the interface of SELECTOR V 3.0.0.

Figure 11 shows the initial screen of the program. From left to right, the calculation options are presented: collector to collector or multiple collectors, respectively.

When opting for the 'collector to collector' option, the corresponding interface in Figure 11, is displayed, where the user can enter the information of the network, to then click on 'characteristics 


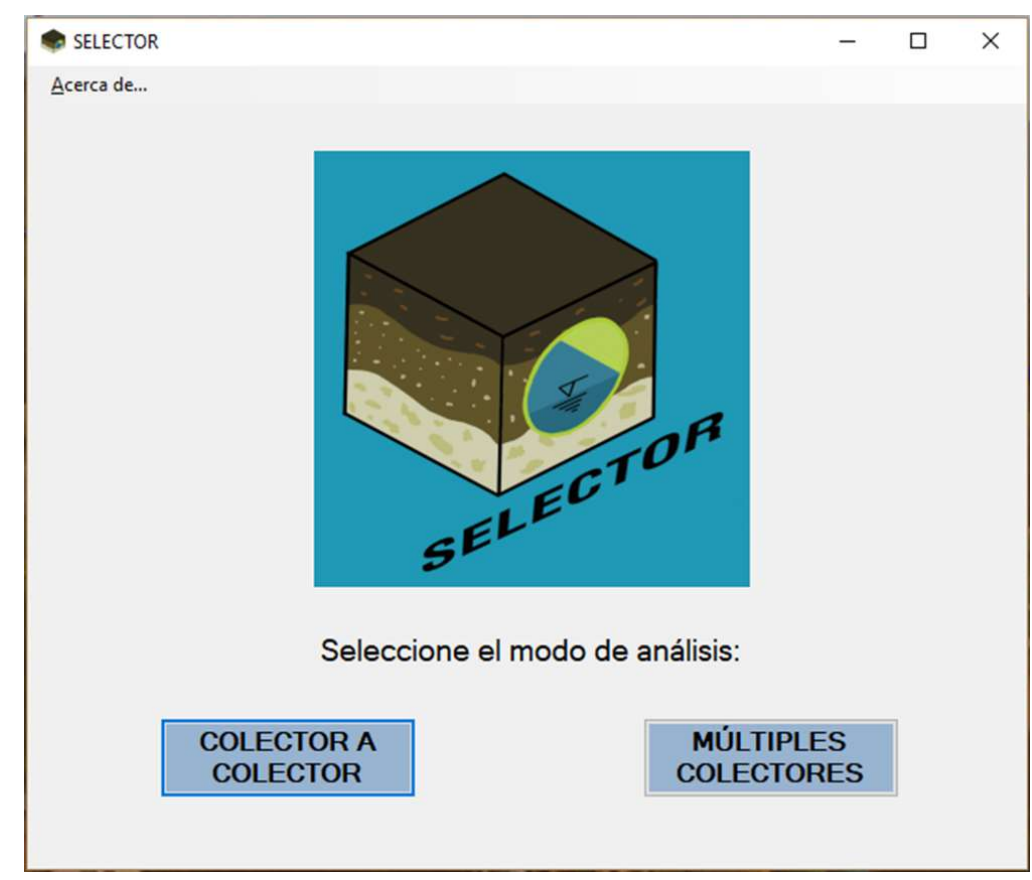

Figure 10. Initial SELECTOR interface

Source: Primary author.

of the collector' located on the right. Clicking on this last button displays the window for completing the eight attributes of the collector (Figure 12). Once the data of the collector has been filled, the 'process' button can be pressed, through which SELECTOR determines the most appropriate TRT for the collector characteristics defined by the user. Finally, in this analysis option, SELECTOR allows exporting the results to a spreadsheet.

SELECTOR also offers the possibility of analyzing several collectors at the same time, for which the 'multiple manifolds' option in Figure 11 must be clicked. In this case, an Excel® file must be imported which has been previously filled with the information of the network and the eight characteristics of the collectors. After the import, SELECTOR generates a window where it shows the quantity and the information of the collectors. Finally, the 'process' button must be clicked to establish the best TRT for each case. As in the 'collector to collector' calculation option, the user can export the answers to an Excel ${ }^{\circledR}$ document. As an example of this, Figure 13 is presented.

Out of the 100 rules identified through data mining, it was found that, although SELECTOR defines the appropriate TRTs, there are four cases with some exceptions. For this reason, the exceptions were included and shown to the user through a pop-up window. Additionally, the button called 'query exceptions' was included, so that the user can consult them when they want. For example, according to SELECTOR, when the diameter is medium, the cross section is circular, the degree of deterioration is medium, the misalignment is small, the deformation of the cross section is medium, 
Methodology for the Selection of Trenchless Sewer Rehabilitation Technologies in Bogotá, Colombia Tovar-Romero., E.L. Valero-Fandiño., J.A. y Cepeda-Ariza., L.

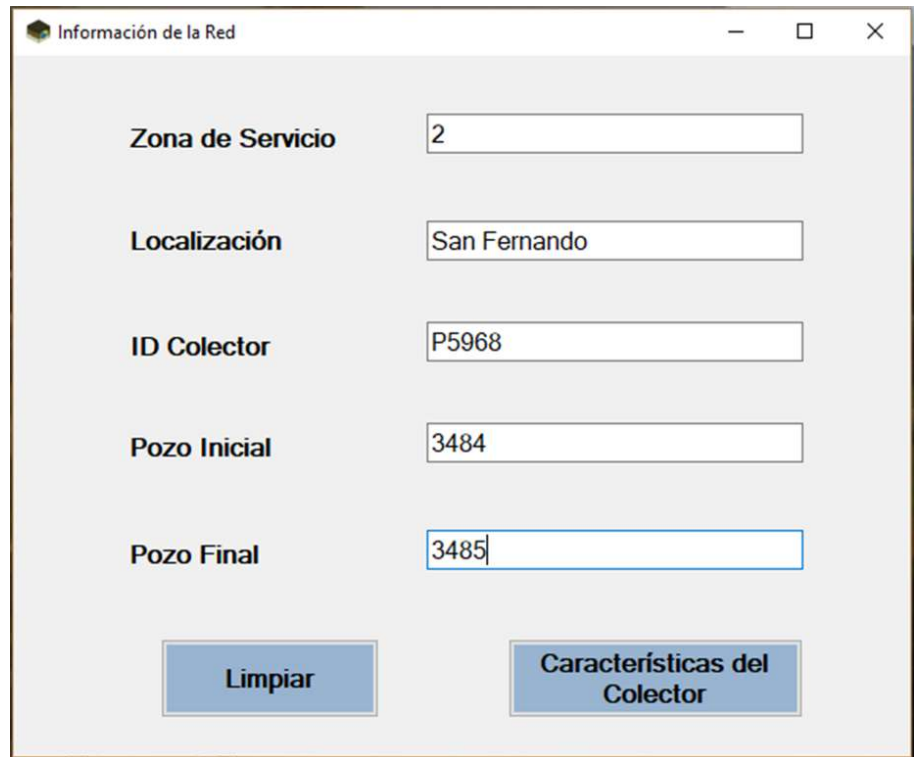

Figure 11. Interface for the filling of information of the network

Source: Primary author.

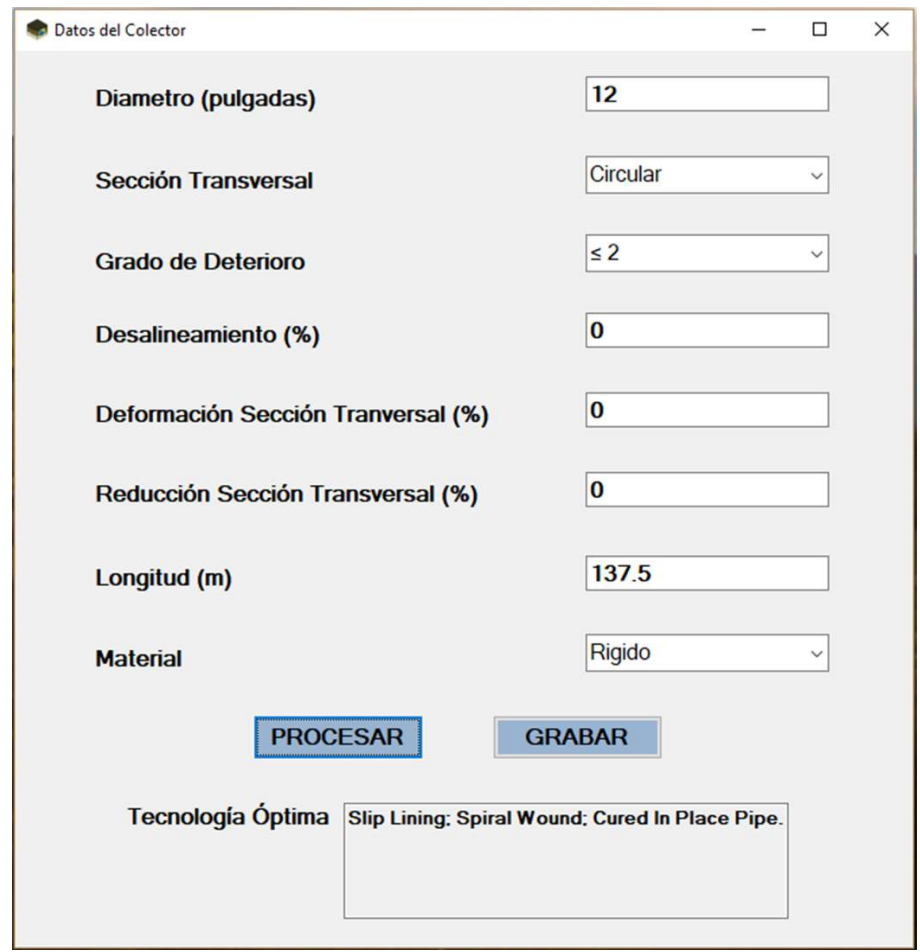

Figure 12. Data collection interface of the collector

Source: Primary author. 


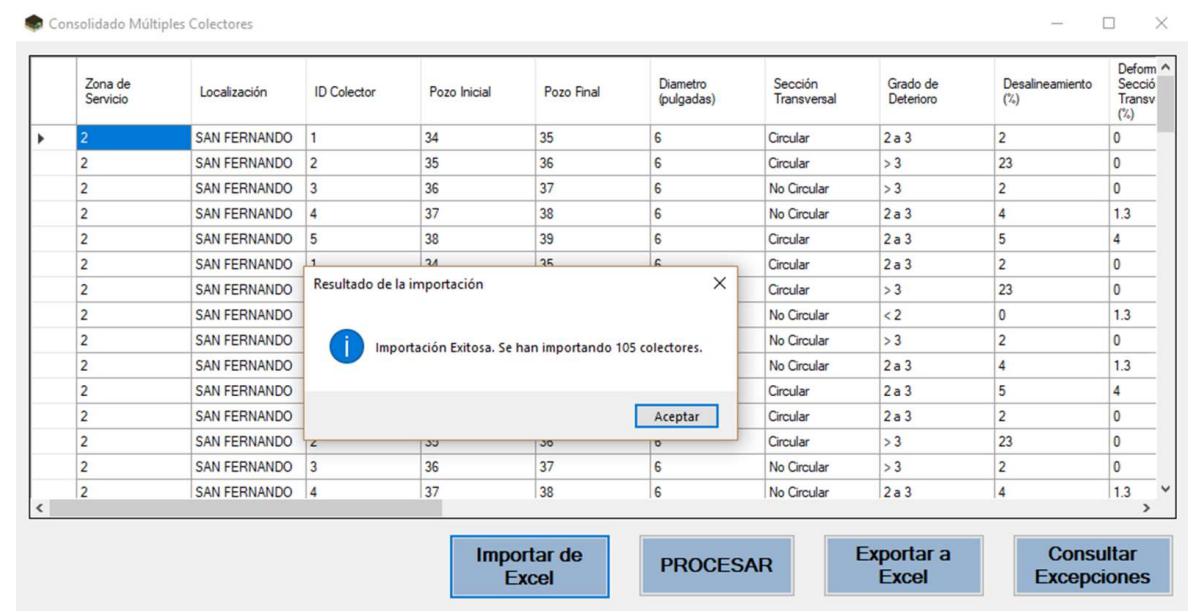

Figure 13. Consolidated information import interface

Source: Primary author.

the reduction of the transversal area is average, the length is extraordinary, and the material is rigid, in $92,2 \%$ of the cases, none of the technologies analyzed applies (NTAA). However, in 7,8\% of cases, CIPP applies. The specific cases in which CIPP applies are shown by SELECTOR as exceptions.

\section{CONCLUSIONS}

SELECTOR consolidates an efficient and accurate methodology for the appropriate selection of TRTs in relation to the characteristics of the collectors subject to rehabilitation. In this way, it can be stated that SELECTOR is a useful, versatile model that is easy to fill out and agile in the processing of information. The information requested by SELECTOR is easily obtained by sewer operators. Moreover, SELECTOR reduces analysis times by facilitating the study of multiple collectors with a single click.

According to all the possible scenarios contemplated on SELECTOR, the technology that has a greater range of individual application is PB, with 146 scenarios, followed by CIPP with 94 and SW with 8. SL does not present individual application scenarios, but it shares 4 application scenarios with the other technologies. Furthermore, there are 1673 scenarios for which none of the analyzed TRTs applies.

The use of the data processing model developed for SELECTOR can be replicated to generate a rehabilitation model for all types of networks. In any case, it is recommended to include geotechnical and economic variables, as well as the type of traffic and access to the network to be rehabilitated. 


\section{ACKNOWLEDGMENTS}

The authors of this article express their gratitude to the EAAB for the information provided to carry out this study.

\section{REFERENCES}

[Asociación Ibérica de Tecnología sin Zanja, 2018] Asociación Ibérica de Tecnología sin Zanja. (2018). Libro blanco de las Tecnologías sin zanja. Asociación Ibérica de Tecnología sin zanja. $\uparrow$ Ver página 107, 108,109

[Carvajal Montealegre, 2015] Carvajal Montealegre, C. J. (2015). Extracción de reglas de clasificación sobre repositorio de incidentes de seguridad informática mediante programación genética. Tecnura, 109-120. https://doi.org/10.14483/udistrital.jour.tecnura.2015.2.a08 个Ver página 110

[Chan, 2017] Chan, W. S. (2017, September 25-27). Pipe Bursting techniques and considerations for successful pipe replacement [Conference presentation]. Trenchless World Congress No Dig MED 2017 Pipe Bursting Techniques and Considerations for Successful Pipe Replacement. Medellín, Colombia. $\uparrow$ Ver página 107, 109

[EAAB, 2001] Empresa de Acueducto y Alcantarillado de Bogotá (EAAB) (2001). Norma técnica de servicio: Aspectos técnicos para la rehabilitación de redes y estructuras de alcantarillado. SISTEC. $\uparrow$ Ver página $107,109,110$

[EAAB, 2010a] Empresa de Acueducto y Alcantarillado de Bogotá (EAAB) (2010a). Norma técnica de servicio: Aspectos técnicos para la inspección de redes y estructuras de alcantarillado. SISTEC. $\uparrow$ Ver página 109,110

[EAAB, 2010b] Empresa de Acueducto y Alcantarillado de Bogotá (EAAB) (2010b). Procedimiento para la renovación de redes PR-GO-04. SISTEC. $\uparrow$ Ver página 107

[EAAB, 2015a] Empresa de Acueducto y Alcantarillado de Bogotá (EAAB) (2015a). Norma técnica de Producto: Materiales del tubo de revestimiento y de resinas en la tecnología tubería curada en sitio (CIPP). SISTEC. $\uparrow$ Ver página 108, 110

[EAAB, 2015b] Empresa de Acueducto y Alcantarillado de Bogotá (EAAB) (2015b). Norma técnica de servicio: Consideraciones de construcción en la técnica de tubería curada en sitio (CIPP). SISTEC. $\uparrow$ Ver página 110 
[EAAB, 2015c] Empresa de Acueducto y Alcantarillado de Bogotá (EAAB) (2015c). Norma técnica de servicio: Consideraciones de diseño en la técnica de tubería curada en sitio (CIPP). SISTEC. $\uparrow$ Ver página 108,110

[EAAB-Treltec, 2010] Empresa de Acueducto y Alcantarillado de Bogotá-Treltec (EAAB-Treltec) (2010). Procedimiento para la renovación de redes por el método del Pipe Bursting. Treltec Ingniería Ltda. 个Ver página 107, 109

[EPA, 2007] EPA (2007). Innovation and Research for Water Infrastructure for the 21st Century: Research Plan EPA/600X-09/003. Office of Research and Development National Risk Management Laboratory. $\uparrow$ Ver página 107

[Jiawei et al., 2012] Jiawei, H., Micheline, K., \& Jian, P. (2012). Data Mining Concepts and Techniques. Elsevier - Morgan Kaufmann. $\uparrow$ Ver página 110

[Mínguez, 2015] Mínguez, F. (2015). Métodos de excavación sin zanja. Universidad Politécnica de Madrid. $\uparrow$ Ver página 107, 109

[Ministerio de Vivienda, Ciudad y Territorio, 2015] Ministerio de Vivienda, Ciudad y Territorio (2015). Sistema de recolección y evacuación de aguas residuales domésticas y aguas lluvias. Viceministerio de agua y saneamiento básico. $\uparrow$ Ver página

[Ministerio de Vivienda, Ciudad y Territorio, 2017] Ministerio de Vivienda, Ciudad y Territorio (2017). Resolución 0330. MVCyT, República de Colombia. $\uparrow$ Ver página 110, 111, 113

[Mongue, 2017] Mongue, O. (2017, September 25-27). Una solución de bajo costo y riesgo mínimo para la rehabilitación de tuberías. [Conference presentation]. Trenchless World Congress No Dig MED 2017 Pipe Bursting Techniques and Considerations for Successful Pipe Replacement. Medellín, Colombia. $\uparrow$ Ver página 107, 109

[Hashash \& Finno, 2008] Hashash, Y. M. A \& Finno, R. J. (2008). Development of new integrated tools for predicting, monitoring, and controlling ground movements due to excavations. Practice Periodical on Structural Design and Construction, 13(1), 4-10. https: / / doi .org/10.1061/ (ASCE) $1084-0680$ (2008) 13:1(4) 个Ver página

[Peña-Abreu et al., 2017] Peña-Abreu, M., Rodríguez-Rodríguez, C. R., \& Piñero-Pérez, P. Y. (2017). Computing with words to feasibility study of software projects. Tecnura, 20(50), 69-84. https: //doi.org/10.14483/22487638.11562 个Ver página

[Pyzoha, 2013] Pyzoha, D. S. (2013). An economical and sustainable alternative to open-cut construction for small-diameter. Journal (American Water Works Association), 105(7), 64-77. https: //doi.org/10.5942/jawwa.2013.105.0097 ^Ver página 107 
[RAE] Real Academia Española. (n.d.). Adjetivo. In Diccionario de la Real Academia Española. http: //dle.rae.es/?id=0ldVsDG $\uparrow$ Ver página

[Rokach \& Maimon, 2007] Rokach, L. \& Maimon, O. (2007). Data Mining With Decision Trees Theory and Applications. World Scientific. https://doi .org/10.1142/6604 个Ver página 110

[Rosado-Gómez \& Verjel-Ibáñez, 2015] Rosado-Gómez, A. A. \& Verjel-Ibáñez, A. (2015). Minería de datos aplicada a la demanda del transporte aéreo en Ocaña, Norte de Santander. Tecnura, 101-114. https://doi.org/10.14483/udistrital.jour.tecnura.2015.3.a08 个Ver página 110

[Sullivan, 2002] Sullivan, E. (2002). "Social costs. ${ }^{\circ}$ f open-cut trenching can be avoided. Journal (American Water Works Association), 94(3), 49-51. https: / / doi .org/10.1002/j.1551-8833.2002. tbo $0432 . x \uparrow$ Ver página 107

[niversity of Waikato, 2016] University of Waikato. (2016). Machine Learning Group at the University of Waikato.https://www.cs.waikato.ac.nz/ml/weka/ Ver página 118

[Vera, 2016] Vera, G. (2016). Underground Engineering and Trenchless Technologies at the Defense of Environment. Procedia Engineering, 165, 1395-1401. https : / / doi . org/10 . 1016 / j . proeng . 2016.11.870 个Ver página 107

[Wavin, 2013] Wavin. (2013). Design manual non-pressure pipe applications. Wain Overseas. $\uparrow$ Ver página $107,109,110$

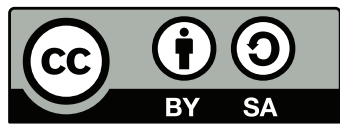

